\title{
RESEARCHES ON THE SUBJECT OF "VIOLENCE AGAINST WOMEN”: A BIBLIOMETRIC ANALYSIS SINCE 2000
}

\author{
İ. Esen YILDIRIM ${ }^{[*]}$ \\ Özlem ERGÜT ${ }^{[* *]}$
}

\begin{abstract}
The purpose of this study is to measure the existing scientific contribution on the subject of "violence against women (VAW)" since 2000. The data set of this research is compiled of the articles searched by the keyword "violence against women" on Web of Science (WOS) data base. These articles were analyzed bibliometrically according to their annual frequency, field of interest, country, institution, journals they were published in and their authors in five-year periods since 2000. Besides the social network among countries, institutions and authors contributed to the VAW literature was disclosed. It is observed that there had been a significant increase in the scientists' interest on the subject of VAW since 2000. It is also remarkable that the USA stands out as the leading country on this subject in all the three periods. The academic cooperation between the authors and the universities that are studying on the subject of VAW has been improved especially starting from 2010. It is believed that the obtained data in this study and presented social network structures among countries, universities and authors would serve as a guide for the improvement of future international cooperative works among the leading universities and researchers that study to protect the women against the violence.
\end{abstract}

Keywords: Violence Against Women, Bibliometrics, Social Network Analysis, Web of Science

JEL Classification: $\mathrm{C} 10$

\section{KADINA YÖNELIKK ŞİDDET ARAŞTIRMALARI: 2000 YILI VE SONRASI İÇİN BİBLIYYOMETRİK BİR ANALİZ}

\section{Özet}

Bu çalışmada, Kadına Yönelik Şiddet konusunda 2000 yılı itibariyle ortaya konulan akademik katkı ölçülmeye çalışılmıştır. Araştırmanın veri seti, Web Of Science (WOS) veri tabanı üzerinden "violence against women" anahtar kelimesi ile derlenen makalelerden oluşturmaktadır. Sözkonusu makaleler, 2000 yılından itibaren beşer yıllık periyodlar için yıl bazındaki sıklık, ilgili oldukları alan,

${ }^{[*]}$ Assoc. Prof., Marmara University, Faculty of Economics, Departmant of Econometrics, Göztepe Campus, KadıköyIstanbul, Turkey, eyildirim@marmara.edu.tr

${ }^{[*]}$ Research Assistant, Ph.D., Marmara University, Faculty of Economics, Departmant of Econometrics, Istanbul, Turkey, ozlem.ergut@marmara.edu.tr 
yayınlandıkları dergi, ülke, kurum ve yazarlar yönünden bibliyometrik olarak analiz edilmiş; ülkeler, kurumlar ve yazarlar arasındaki sosyal ağ yapısı ortaya çıkarılmıştır. 2000'den bu yana akademisyenlerin Kadına Yönelik Şiddet konusuna olan ilgisinde monoton bir artış olduğu gözlenmiştir. Bu konudaki araştırmalarda lider ülkenin ABD olduğu anlaşılmaktadır. Özellikle 2010 ve sonrasında Kadına Yönelik Şiddet konusunda çalışan üniversiteler ve yazarlar arasında akademik işbirliğinin yoğunlaşttğg 1 göze çarpmaktadır. Üniversiteler ve yazarlar için tespit edilen sosyal ağların, Kadına Yönelik Şiddet konusunda ileride gerçekleştirilecek akademik organizasyonlar için önemli bir enformasyon sağlayacağ 1 düşünülmektedir.

Anahtar Kelimeler: Kadına Yönelik Şiddet, Bibliyometri, Sosyal Ağ Analizi, Web of Science

JEL Sınıflaması: C10

\section{Introduction}

Brought to prominence by feminist organizations in the 1980s and thereafter regarded as a "social topic", and further defined in 2002 as "a health problem with first priority" by the World Health Organization, violence against women (VAW) which is widely accepted as a "violation of human rights" based on sexual discrimination, is an important, agenda-setting issue today.

It is estimated that 35 percent of women worldwide have experienced either physical and/or sexual intimate partner violence or sexual violence by a non-partner at some times in their lives. Some national studies show that up to 70 percent of women have experienced physical and/or sexual violence from an intimate partner in their lifetime. ${ }^{1}$ Forty three percent of women in the 28 European Union Member States have experienced some form of psychological violence by an intimate partner in their lifetime. ${ }^{2}$

Worldwide, more than 700 million women alive today were married as children (below 18 years of age). Child brides are often unable to effectively negotiate safe sex, becoming pregnant as well as sexually having transmitted infections, including Human Immunodeficiency Virus (HIV). ${ }^{3}$

It is clear that further scientific researches on VAW will be the basis of the determination of causes and effects of this problem and development of possible solution suggestions.

In 1994, through the Violence against Women Act (VAWA), Congress directed the National Research Council to develop a research agenda aimed at broadening the understanding of the scope and dynamics of domestic violence and rape. The council concluded that significant gaps exist in understanding the extent and causes of VAW and the impact and effectiveness of preventive and treatment interventions. In order to begin filling those gaps, the panel recommends a research agenda to facilitate development in four major areas: preventing violence against women, improving research methods, building knowledge about violence against women, and developing the research infrastructure. ${ }^{4}$

1 United Nations, The World's Women 2015, Trends and Statistics, 2015; World Health Organization, Violence Against Women, İntimate Partner and Sexual Violence Against Women, 2013.

2 European Union Agency for Fundamental Rights, Violence Against Women: An EU-Wide Survey, 2014.

3 UNICEF, Ending Child Marriage Progress and Prospects, 2014.

4 Nancy Crowell - Ann Burgess, Understanding Violence Against Women, Washington, DC: National Academy 
When the studies conducted within this scope were evaluated as of 2015, it is clearly seen that there had been a great progress on the subject of VAW. Thirty years ago, the "violence against women" and violence research would not be expected to find such an audience and funding streams and a commitment to influence public policy on behalf of women. In recent years, the increased attention on the topics like the intergenerational effect of violence on children, the antecedents of abusive relationships, the long-term consequences of domestic violence, etc. have made the subject more prominent. Consequently, there have been considerable scientific advances and development on violence against women and family violence in a relatively short period of time. ${ }^{5}$

During the past three decades, published literature on VAW has significantly increased, and its distribution across journals and by discipline has changed appreciably. As a consequence of this progress, an urgent need has arisen for the investigations of bibliometric studies on VAW. The conducted investigations within the scope of this study will be an efficient guideway for the VAW researchers by presenting the currently achieved scientific contribution on VAW studies.

\section{Materials and Methods}

The bibliometrics is a statistics-based approach that gives summarized information of the published studies in a specific discipline or field. The bibliometric analyses have a great impact to develop future colloborations and enhance publishing strategies through the existing situation analyses on the selected field.

As Sengupta has stated "the field literature can be analyzed in three different ways: including descriptive bibliometrics involving systematic compilations of literature, evaluative bibliometrics, and citation analyses to show how many times an article or other form of publication has been referenced in other publications - and directories, which are listings of scientists and scholars who are the primary authors of articles published in the journals of interest". ${ }^{6}$

Social Network Analysis (SNA) is one of the most frequently applied analyses as a bibliometric mapping technique. SNA provides visual representation of the relation structure among the units (nodes) such as people, institutions, countries, etc. The structure formed by the nodes and the connections among the nodes called as a "network".

In SNA, several centrality indexes are measured to reveal the relations among the network density and network units. The values of the centrality index vary between 0 and 1 . The index is " 0 " if all units centrality is equal and " 1 " if one unit dominates the others. The most frequently used centrality indexes are degree centrality, closeness centrality and betweenness centrality. ${ }^{7}$

Press, 1996; Carol E.Jordan, "Advancing the Study of Violence Against Women: Evolving Research Agendas Into Science”, Violence Against Women, 15, 2009, s. 393-419.

5 Carol E.Jordan, a.g.m.; Beth E.Richie, "Research on Violence Against Women and Family Violence: The Challenges and The Promise", Violence Against Women and Family Violence: Developments in Research, Practice and Policy, Ed: B. S. Fisher Rockville, MD: National Criminal Justice Reference Service, 2004, s. IV-1-3-IV-1-8.

6 I. N. Sengupta, “Bibliometrics, informetrics, scientometrics, and librametrics: An overview”, Libri, 42(2), 1992, s.75-98.

7 Evelien Otte - Ronald Rousseau, "Social Network Analysis: A Powerful Strategy, Also For The Information Sciences”, Journal of Information Science, 28(6), 2002, s.441-453. 
Degree Centrality (CD) of a node is the indicator of a number of connections linked to that node. A node having a high degree centrality value and an easily access by the other nodes are defined as a "central node".

$$
C_{D}=\frac{\sum\left(C_{D}^{*}-C_{D}(x)\right.}{(n-2)}
$$

$C_{D}^{*}$ : The measure of highest unit degree centrality

Closeness centrality $(\mathrm{Cc})$ is an indicator of a direct or indirect closeness of nodes to all others. The week or strong connection of nodes is determined with the closeness measure. Closeness is equal to the total number of shortest paths from all vertices to all others that pass through that node (directly or indirectly). It shows how fast a node can be attached to the others.

$$
C_{c}=(2 n-3)\left(\sum C_{\dot{c}}-C_{c}(x)\right) /(n-1)(n-2)
$$

$C_{\dot{C}}^{*}$ : The measure of highest unit closeness centrality

Betweenness Centrality $(C B)$ is a degree of how a node is located between other nodes in the network. High level of betweenness of a node shows a high coordination and bridge ability of that node over flows in the network.

$$
C_{\bar{B}}=\frac{C_{\bar{B}}^{*}-C_{\bar{B}}(x)}{(n-1)}
$$

$C_{\bar{B}}^{*}:$ The measure of highest unit betweenness centrality

Clustering is the state of strong and weak connections of the nodes in the network. The clustering of the nodes in small groups is determined with the clustering index. Watts-Strogatz Model was the clustering method used in this study.

Aiming to reveal the scientific contribution on the subject of VAW; a detailed bibliometric analyses of the articles published in Science Citation Index (SCI), Social Science Citation Index (SSCI) and Art \&Humanities Citation Index (AHCI) on this topic since 2000 have been conducted. For the purpose of this review, the bibliographic databases of Web of Science were searched. The keyphrase "violence against women" was used and the index years of 2000-2004, 2005-2009 and 2010-2014 were chosen as three selected time periods to conduct a review of the literature within the database.

As a result of the conducted analyses, the frequency of appearance of the topic "VAW" in the scientific world, the change of scientific performance by time, the scientific contributions and its essential actors (countries, institutions and people) in the field were revealed. Statistical goals determined in the study were as follows: 
1. Obtaining biometric statistics from the studies on the subject "VAW" based on year, keywords, countries, authors, journals and universities.

2. Analyzing social networks among authors, universities and countries in the articles on the subject "VAW".

Bibexcel, Pajek ve VOSViewer were used in the analysis of the data set.

\section{Distribution of Publications on VAW According to Document Type}

The articles on VAW were searched with the keywords of "Violence against Women" in WOS database. The distribution of the publications according to document type in five-year periods is presented in Figure 3.1. The correction, letter, reprint, news item, book chapter and script types of publications which were observed as a few among all documents, are shown under the category of "Other".

Figure I: The Distribution of The Publications on VAW According to Document Type

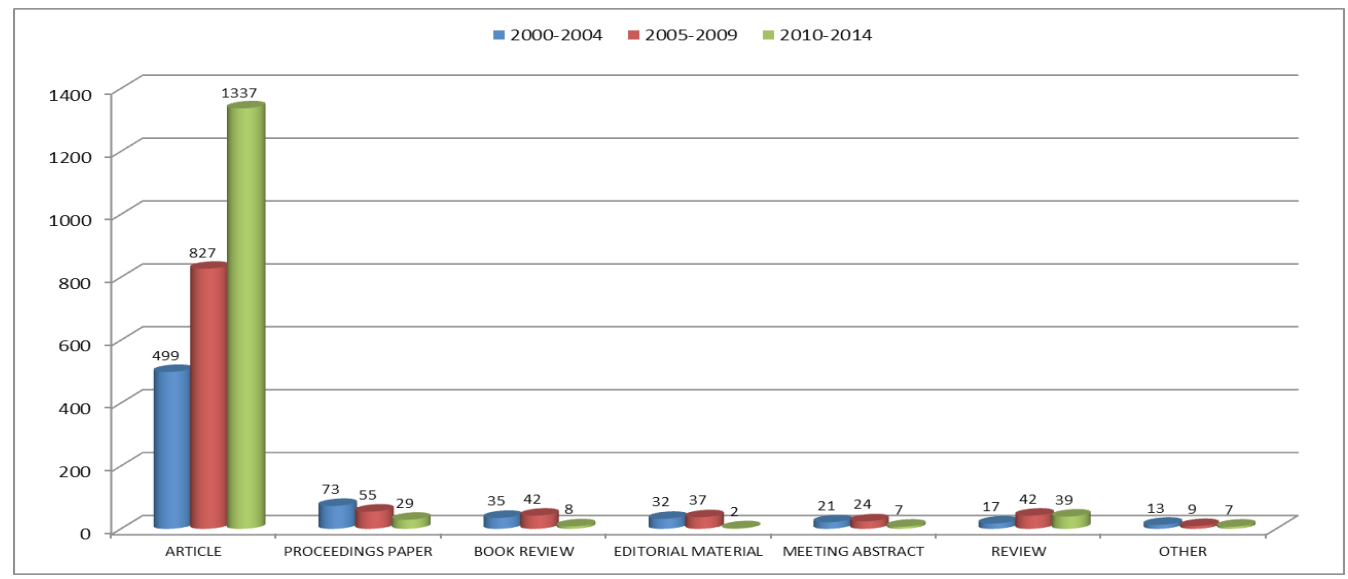

As can be seen at the Figure 3.1, 3155 documents in total were found; 690 of which were between 2000 and 2004, 1036 were between 2005 and 2009, and 1429 were between 2010 and 2014. The number of publications between 2010 and 2014 doubled that of published between 2000 and 2004.

It is seen that while there was an increase in the number of articles and reviews, the number of other document types was decreased in every five years since 2000. This data reveals that researchers on VAW has interested especially on article-based publications rather than other types. It was also determined that articles comprised $85 \%$ of all available documents. Therefore, biometric analyses were performed on the articles. 
Distribution of the articles on VAW according to the published years is shown in Figure 3.2. It was found that a total of 2663 articles were published on VAW; of which 499 articles were between 2000-2004, 827 was between 2005-2009 and 1337 was between 2010 and 2014.

Figure 2: Distribution of the Articles on VAW According to Published Years

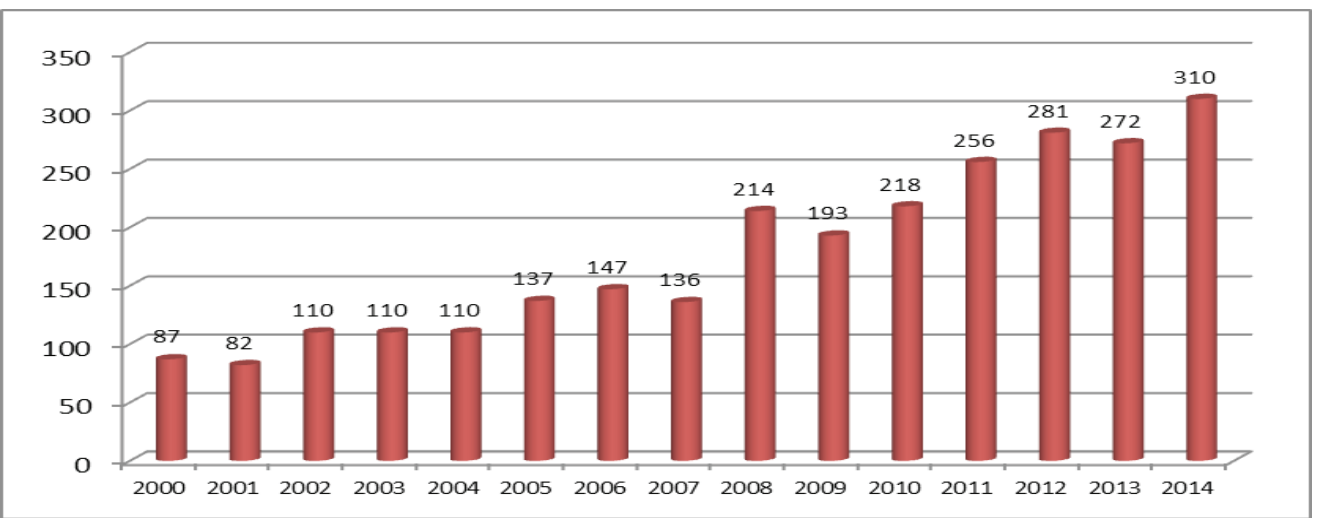

When the Figure 3.2 is evaluated, there is a steady increase in the number of published articles on VAW in the period of 2000-2014. The number of publications in 2014 was almost 3.5 times that of in 2000. This finding indicates that there has been a growing interest by the scientists on the subject of VAW since 2000 .

\section{Authors Who Have The Highest Contributions to VAW Literature}

The authors who have the highest contribution to VAW literature since 2000 is one of the subjects undertaken within the scope of this study. Authors with at least five publications on VAW in previously mentioned five year periods are shown in Table 4.1 . 
Table I: The Authors Who Have The Highest Contribution to VAW Literature

\begin{tabular}{|c|c|c|c|c|c|}
\hline AUTHOR & 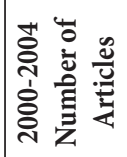 & AUTHOR & 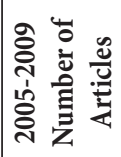 & AUTHOR & 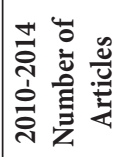 \\
\hline Jewkes R & 7 & Silverman Jg & 12 & Watts C & 16 \\
\hline Brownridge Da & 6 & Brownridge $\mathrm{Da}$ & 9 & Yount Km & 12 \\
\hline Garcia-Moreno C & 6 & Gracia E & 9 & Decker Mr & 11 \\
\hline Mcfarlane J & 6 & Raj A & 9 & Schraiber Lb & 11 \\
\hline Saltzman Le & 6 & Decker Mr & 8 & Vives-Cases C & 11 \\
\hline Thompson Mp & 6 & Naved Rt & 8 & Kiss L & 8 \\
\hline Haj-Yahia Mm & 5 & Chan Kl & 7 & Lila M & 8 \\
\hline Johnson $\mathrm{H}$ & 5 & D'oliveira Afpl & 7 & Silverman Jg & 8 \\
\hline \multirow[t]{17}{*}{ Malecha A } & 5 & Felson $\mathrm{Rb}$ & 7 & Stockl H & 8 \\
\hline & & Vives-Cases C & 7 & Emmelin M & 7 \\
\hline & & Gupta J & 6 & Gracia E & 7 \\
\hline & & Haj-Yahia Mm & 6 & Mcfarlane J & 7 \\
\hline & & Herrero J & 6 & Schuler Sr & 7 \\
\hline & & Persson La & 6 & Chan Kl & 6 \\
\hline & & Schraiber Lb & 6 & Fong Dyt & 6 \\
\hline & & Jewkes R & 5 & Gupta J & 6 \\
\hline & & Krantz G & 5 & Heise L & 6 \\
\hline & & Sorenson Sb & 5 & Mccauley Hl & 6 \\
\hline & & Valdez-SantiagoR & 5 & Naved Rt & 6 \\
\hline & & & & Zakar Mz & 6 \\
\hline & & & & Zakar R & 6 \\
\hline & & & & Rennison $\mathrm{Cm}$ & 5 \\
\hline & & & & Tiwari A & 5 \\
\hline & & & & Wathen $\mathrm{Cn}$ & 5 \\
\hline & & & & Zimmerman C & 5 \\
\hline
\end{tabular}

Parallel to the increase in the number of publications according to year, it is observed that there was also an increase in the number of publications per author. Additionally, there were also some authors studying the subject over five years. The social network structure among the authors will be studied separately.

\section{Countries Making The Highest Contribution to The Literature of VAW}

The distribution of the articles on the subject of VAW according to the countries they were published in is presented at Table 5.1. It is remarkable that the USA stands out as the leading country on this subject in all the three periods. For the last 15 years, 1165 (44\%) of the 2663 articles tracked in WOS were published in the USA. 
England is the second highest contributor to VAW literature for the period of 2000-2014. Canada, Switzerland, Australia, South Africa, Brazil, Mexico and India are the other leading countries found to be at the forefront.

Table 2: Distribution of the Published Articles on VAW According to Country

\begin{tabular}{|c|c|c|c|c|c|}
\hline Country & 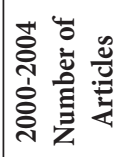 & Country & 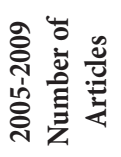 & Country & 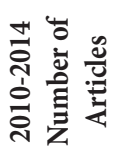 \\
\hline USA & 261 & USA & 362 & USA & 542 \\
\hline CANADA & 47 & CANADA & 75 & ENGLAND & 138 \\
\hline ENGLAND & 36 & ENGLAND & 50 & BRAZIL & 100 \\
\hline S. AFRICA & 19 & BRAZIL & 44 & SPAIN & 86 \\
\hline MEXICO & 13 & SPAIN & 41 & CANADA & 83 \\
\hline SWEDEN & 13 & SWEDEN & 33 & SWEDEN & 71 \\
\hline AUSTRALIA & 12 & AUSTRALIA & 29 & AUSTRALIA & 59 \\
\hline INDIA & 12 & MEXICO & 26 & S. AFRICA & 43 \\
\hline ISRAEL & 12 & ISRAEL & 22 & INDIA & 42 \\
\hline BRAZIL & 10 & S. AFRICA & 22 & TURKEY & 31 \\
\hline SWITZERLAND & 8 & INDIA & 16 & GERMANY & 24 \\
\hline ITALY & 7 & TURKEY & 13 & MEXICO & 22 \\
\hline BANGLADESH & 6 & BANGLADESH & 12 & ISRAEL & 21 \\
\hline GERMANY & 6 & CHINA & 12 & CHINA & 20 \\
\hline TURKEY & 6 & SWITZERLAND & 12 & NETHERLANDS & 19 \\
\hline DENMARK & 5 & GERMANY & 10 & NIGERIA & 19 \\
\hline NETHERLANDS & 5 & NIGERIA & 10 & SWITZERLAND & 19 \\
\hline CHINA & 5 & NORWAY & 9 & ITALY & 17 \\
\hline N. ZEALAND & 4 & FRANCE & 7 & UGANDA & 16 \\
\hline NORWAY & 4 & N. ZEALAND & 6 & FRANCE & 15 \\
\hline NICARAGUA & 3 & IRAN & 5 & NORWAY & 15 \\
\hline SPAIN & 3 & ITALY & 5 & PAKISTAN & 15 \\
\hline
\end{tabular}

There was no correlation between the countries having the highest publication rates on VAW and the occurrence of VAW incidents in these countries. Providing the highest funds for the research on VAW naturally makes the USA the most contributing country on the subject.

The recently conducted studies have shown that lack of funding and the level of limited funding on individual grants are the most important barriers to realize empiricial researches on the subject of VAW. ${ }^{8}$

8 Nancy Crowell - Ann Burgess, a.g.k., C.E.Jordan, a.g.m., s. 393-419; Candace Kruttschnitt, Brenda McLaughlin, 
The articles on VAW were further investigated from the points of their written language. Table 5.2 shows that 2412 (91\%) of the articles, undertaken the subject of VAW since 2000, are written in English. It should be noted that English as being the predominant language was an expected consequence of the fact that USA, Canada and England are the countries that publish the highest number of articles on VAW.

Table 3: Distribution of the Articles on VAW According to the Written Language

\begin{tabular}{|l|c|l|c|l|c|}
\hline Language & $\begin{array}{c}\text { 2000-2004 } \\
\text { Number of } \\
\text { Articles }\end{array}$ & Language & $\begin{array}{c}\text { 2005-2009 } \\
\text { Number of } \\
\text { Articles }\end{array}$ & \multicolumn{1}{|c|}{ Language } & $\begin{array}{c}\text { 2010-2014 } \\
\text { Number of } \\
\text { Articles }\end{array}$ \\
\hline English & 474 & English & 721 & English & 1217 \\
\hline French & 11 & Spanish & 44 & Portuguese & 48 \\
\hline Spanish & 9 & Portuguese & 27 & Spanish & 40 \\
\hline German & 3 & German & 12 & French & 10 \\
\hline Portuguese & 2 & French & 11 & German & 9 \\
\hline & & Croatian & 3 & Swedish & 4 \\
\hline & & Dutch & 3 & Turkish & 3 \\
\hline & & Swedish & 2 & Croatian & 2 \\
\hline & & & & Italian & 2 \\
\hline & & & & Slovenian & 2 \\
\hline
\end{tabular}

The other most often used languages are found to be Spanish, Portuguese, French and German.

\section{Mostly Studied Fields on the Subject of VAW}

An important measure of the state of the written knowledge on VAW relates to the disciplines of the scientists who publish in the field. A comprehensive research is required from the points of behavioral, social, biomedical, and legal sciences and other disciplines including especially the subjects of criminal justice, medicine, public health, psychology, psychiatry, sociology, social work, law, etc. in order to understand violence thoroughly. Since each discipline operates with unique theoretical models and research methodologies, this interdisciplinary research brings additional challenges to the field. This variability limits the generalization of the findings on the subject and makes some areas of literature inaccessible to all researchers. ${ }^{9}$

Carol Petrie, Advancing the Federal Research Agenda on Violence Against Women, Washington, DC: National Academy Press, 2002.

9 Nancy Crowell - Ann Burgess, a.g.k., C.E.Jordan, a.g.m., s. 393-419; David A. Ford, Ronet Bachman, Monica R.Friend, Michelle Meloy, Controlling Violence Against Women: A Research Perspective On The 1994 VAWA's Criminal Justice Impacts. Washington, DC: U.S. Department of Justice, NIJ, 2002; C.Kruttschnitt, B.McLaughlin, C.Petrie, a.g.k. 
Based on this fact; the most studied areas on the subject of VAW over the last 15 years such as Women Studies, Public Environmental Occupational Health, Family Studies, Criminology, Psychology, Medicine Internal and Social Sciences, Psychiatry, Sociology and Law are analyzed and shown in Table 6.1.

Table 4: Distribution of The Articles According to The Study Areas on VAW

\begin{tabular}{|c|c|c|c|c|c|}
\hline WOS Category & 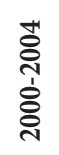 & WOS Category & 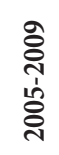 & WOS Category & 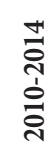 \\
\hline Women Studies & 113 & $\begin{array}{l}\text { Public Environmental } \\
\text { Occupational Health }\end{array}$ & 188 & $\begin{array}{l}\text { Public Environmental } \\
\text { Occupational Health }\end{array}$ & 275 \\
\hline $\begin{array}{l}\text { Public Environmental } \\
\text { Occupational Health }\end{array}$ & 82 & Women Studies & 149 & Women Studies & 227 \\
\hline Family Studies & 64 & Family Studies & 105 & Criminology Penology & 180 \\
\hline Criminology Penology & 56 & Criminology Penology & 100 & Family Studies & 178 \\
\hline Medicine General Internal & 41 & \begin{tabular}{|l} 
Psychology \\
Multidisciplinary
\end{tabular} & 57 & Psychology Applied & 88 \\
\hline Psychology Applied & 39 & Psychology Applied & 45 & Psychology Clinical & 84 \\
\hline $\begin{array}{l}\text { Psychology } \\
\text { Multidisciplinary }\end{array}$ & 34 & Social Work & 44 & Medicine General Internal & 65 \\
\hline Obstetrics Gynecology & 33 & Psychology Clinical & 42 & \begin{tabular}{|l} 
Psychology \\
Multidisciplinary
\end{tabular} & 64 \\
\hline Psychology Clinical & 27 & Psychiatry & 38 & Obstetrics Gynecology & 59 \\
\hline Law & 26 & Medicine General Internal & 35 & Nursing & 58 \\
\hline Social Work & 25 & Obstetrics Gynecology & 34 & Social Work & 56 \\
\hline Psychiatry & 20 & $\begin{array}{l}\text { Social Sciences } \\
\text { Biomedical }\end{array}$ & 33 & Psychiatry & 52 \\
\hline Psychology Social & 20 & Nursing & 31 & Sociology & 51 \\
\hline $\begin{array}{l}\text { Social Sciences } \\
\text { Biomedical }\end{array}$ & 20 & Sociology & 31 & Political Science & 45 \\
\hline Sociology & 17 & Law & 26 & $\begin{array}{l}\text { Social Sciences } \\
\text { Interdisciplinary }\end{array}$ & 41 \\
\hline $\begin{array}{l}\text { Social Sciences } \\
\text { Interdisciplinary }\end{array}$ & 12 & \begin{tabular}{|l|} 
Social Sciences \\
Interdisciplinary \\
\end{tabular} & 25 & Health Policy Services & 37 \\
\hline Political Science & 10 & History & 22 & Law & 35 \\
\hline Communication & 9 & Psychology Social & 19 & \begin{tabular}{|l|} 
Social Sciences \\
Biomedical \\
\end{tabular} & 33 \\
\hline Area Studies & 8 & Anthropology & 17 & Psychology Social & 23 \\
\hline Anthropology & 6 & Area Studies & 17 & Social Issues & 22 \\
\hline $\begin{array}{l}\text { Education Educational } \\
\text { Research }\end{array}$ & 6 & Political Science & 17 & Area Studies & 20 \\
\hline Emergency Medicine & 6 & Health Policy Services & 15 & History & 20 \\
\hline Health Policy Services & 6 & International Relations & 15 & International Relations & 17 \\
\hline Nursing & 6 & Social Issues & 15 & Psychology & 17 \\
\hline
\end{tabular}




\section{Journals That Published The Highest Number Of Articles On VAW}

The literature on specific field should also be evaluated by analyzing its distribution across journals to support the existing citations analyses across databases, keywords, and years. In the library sciences, the "law of concentration" describes the way in which the literature of a discipline is spread across journals ${ }^{10}$, and its use allows identification of core and peripheral journals in the field. ${ }^{11}$

The journals in the field that have published the highest number of articles on VAW over the last 15 years are searched in detail with this purpose and the results is shown in Table 7.1. These are, primarily, Violence against Women (198 articles) and Journal of Interpersonal Violence (156 articles), together with Journal of Family Violence, Social Science Medicine, and Womens Studies International Forum.

Table 5: Journals That Published the Highest Number of Articles on VAW

\begin{tabular}{|c|c|c|c|c|c|}
\hline Journal & 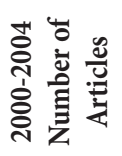 & Journal & 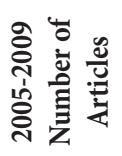 & Journal & 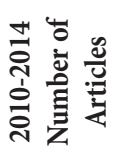 \\
\hline $\begin{array}{l}\text { Violence Against } \\
\text { Women }\end{array}$ & 55 & $\begin{array}{l}\text { Violence Against } \\
\text { Women }\end{array}$ & 65 & $\begin{array}{l}\text { Journal Of } \\
\text { Interpersonal } \\
\text { Violence }\end{array}$ & 82 \\
\hline $\begin{array}{l}\text { Journal Of } \\
\text { Interpersonal } \\
\text { Violence }\end{array}$ & 33 & $\begin{array}{l}\text { Journal Of } \\
\text { Interpersonal Violence }\end{array}$ & 41 & $\begin{array}{l}\text { Violence Against } \\
\text { Women }\end{array}$ & 78 \\
\hline $\begin{array}{l}\text { International Journal } \\
\text { Of Gynecology } \\
\text { Obstetrics }\end{array}$ & 17 & $\begin{array}{l}\text { Journal Of Family } \\
\text { Violence }\end{array}$ & 28 & $\begin{array}{l}\text { Journal Of Family } \\
\text { Violence }\end{array}$ & 46 \\
\hline $\begin{array}{l}\text { Social Science } \\
\text { Medicine }\end{array}$ & 12 & Social Science Medicine & 19 & Bmc Public Health & 29 \\
\hline $\begin{array}{l}\text { Journal Of Family } \\
\text { Violence }\end{array}$ & 10 & $\begin{array}{l}\text { Revista De Saude } \\
\text { Publica }\end{array}$ & 14 & Bmc Womens Health & 15 \\
\hline $\begin{array}{l}\text { Womens Studies } \\
\text { International Forum }\end{array}$ & 10 & $\begin{array}{l}\text { Womens Studies } \\
\text { International Forum }\end{array}$ & 13 & $\begin{array}{l}\text { Revista De Saude } \\
\text { Publica }\end{array}$ & 15 \\
\hline $\begin{array}{l}\text { American Journal Of } \\
\text { Preventive Medicine }\end{array}$ & 7 & $\begin{array}{l}\text { International Journal } \\
\text { Of Gynecology } \\
\text { Obstetrics }\end{array}$ & 12 & $\begin{array}{l}\text { Social Science } \\
\text { Medicine }\end{array}$ & 15 \\
\hline $\begin{array}{l}\text { Nouvelles Questions } \\
\text { Feministes }\end{array}$ & 7 & $\begin{array}{l}\text { Annals Of The New } \\
\text { York Academy Of Sc. }\end{array}$ & 11 & $\begin{array}{l}\text { Violence And } \\
\text { Victims }\end{array}$ & 15 \\
\hline
\end{tabular}

10 E.Garfield, “The Mystery of The Transposed Journal Lists: Wherein Bradford's Law of Scattering Is Generalized to Garfield's Law of Concentration”, Essays of an Information Scientist, 1, 1977, s.222-223.

11 Carol E.Jordan, "Advancing the Study of Violence Against Women: Evolving Research Agendas Into Science", Violence Against Women, 15, 2009, s. 393-419. 


\begin{tabular}{|c|c|c|c|c|c|}
\hline $\begin{array}{l}\text { American Journal Of } \\
\text { Public Health }\end{array}$ & 6 & \begin{tabular}{|l|} 
Violence And \\
Exploitation Against \\
Women And Girls \\
\end{tabular} & 11 & $\begin{array}{l}\text { Womens Studies } \\
\text { International Forum }\end{array}$ & 15 \\
\hline $\begin{array}{l}\text { Journal Of } \\
\text { Comparative Family } \\
\text { Studies }\end{array}$ & 6 & $\begin{array}{l}\text { Journal Of Marriage } \\
\text { And Family }\end{array}$ & 10 & $\begin{array}{l}\text { Journal Of Womens } \\
\text { Health }\end{array}$ & 14 \\
\hline $\begin{array}{l}\text { Psychology Of } \\
\text { Women Quarterly }\end{array}$ & 6 & Salud Mental & 10 & \begin{tabular}{|l} 
Cadernos De Saude \\
Publica
\end{tabular} & 12 \\
\hline $\begin{array}{l}\text { Reproductive Health } \\
\text { Matters }\end{array}$ & 6 & Bmc Public Health & 8 & $\begin{array}{l}\text { Trauma Violence } \\
\text { Abuse }\end{array}$ & 12 \\
\hline $\begin{array}{l}\text { Academic Emergency } \\
\text { Medicine }\end{array}$ & 5 & $\begin{array}{l}\text { Salud Publica De } \\
\text { Mexico }\end{array}$ & 8 & \begin{tabular}{|l|} 
Ciencia Saude \\
Coletiva
\end{tabular} & 11 \\
\hline $\begin{array}{l}\text { American Journal } \\
\text { Of Community } \\
\text { Psychology }\end{array}$ & 5 & Saude E Sociedade & 8 & Global Health Action & 11 \\
\hline Child Abuse Neglect & 5 & Trauma Violence Abuse & 8 & $\begin{array}{l}\text { Maternal And Child } \\
\text { Health Journal }\end{array}$ & 10 \\
\hline $\begin{array}{l}\text { Journal Of Social } \\
\text { Distress And The } \\
\text { Homeless }\end{array}$ & 5 & Aggressive Behavior & 7 & Plos One & 10 \\
\hline \multirow[t]{4}{*}{ Salud Mental } & 5 & $\begin{array}{l}\text { American Journal Of } \\
\text { Public Health }\end{array}$ & 7 & $\begin{array}{l}\text { Revista Da Escola De } \\
\text { Enfermagem Da Usp }\end{array}$ & 10 \\
\hline & & $\begin{array}{l}\text { Reproductive Health } \\
\text { Matters }\end{array}$ & 7 & $\begin{array}{l}\text { Indian Journal Of } \\
\text { Gender Studies }\end{array}$ & 9 \\
\hline & & & & $\begin{array}{l}\text { Men And } \\
\text { Masculinities }\end{array}$ & 9 \\
\hline & & & & $\begin{array}{l}\text { Qualitative Health } \\
\text { Research }\end{array}$ & 9 \\
\hline
\end{tabular}

Sengupta stated that in building on Garfield's law of concentration noted above, a new bibliometric law has been proposed. This new law states that during phases of robust growth of knowledge in a scientific discipline, articles of interest to that discipline appear in increasing number in journals distant from that field. ${ }^{12}$ Either the VAW literature is an exception to the law, or the field is yet to see the largest period of growth as measured by a distribution of its literature beyond victimization-specific journals. Finally, the stalking literature is more heavily concentrated in forensic, criminal justice, and psychiatric journals (not unlike the way the earliest VAW-specific literature began) and in journals outside the United States.

\section{Universities With The Highest Number of Articles Published On VAW}

Universities with the highest number of articles published on VAW are shown in Table 8.1. It was found that the Harvard University overall being in the first place and the other universities in the USA are the institutions that have the highest contribution on VAW. It should be remembered here that USA was the country that contributes most to the VAW literature, as well.

12 I. N. Sengupta, a.g.m., s.75-98. 
Table 6: Universities With the Highest Number of Articles Published on VAW

\begin{tabular}{|c|c|c|c|c|c|}
\hline University & 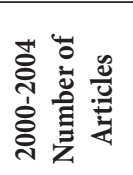 & University & 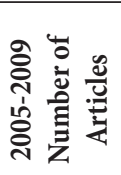 & University & 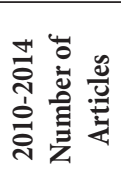 \\
\hline Univ Missouri & 9 & Harvard Univ & 16 & Univ Sao Paulo & 28 \\
\hline Univ Texas & 8 & Boston Univ & 15 & Emory Univ & 27 \\
\hline Univ Manitoba & 8 & Univ N Carolina & 13 & Harvard Univ & 27 \\
\hline Univ Toronto & 8 & $\begin{array}{l}\text { Johns Hopkins } \\
\text { Univ }\end{array}$ & 13 & London Sch Hyg \& Trop Med & 25 \\
\hline Harvard Univ & 8 & Univ Sao Paulo & 13 & Umea Univ & 22 \\
\hline Univ N Carolina & 8 & Univ Kentucky & 12 & Univ Toronto & 18 \\
\hline Univ Iowa & 7 & $\begin{array}{l}\text { Univ Calif Los } \\
\text { Angeles }\end{array}$ & 12 & Univ Calif Berkeley & 17 \\
\hline Univ Wisconsin & 7 & Emory Univ & 12 & Univ Witwatersrand & 17 \\
\hline $\begin{array}{l}\text { Texas Womans } \\
\text { Univ }\end{array}$ & 7 & Karolinska Inst & 11 & Michigan State Univ & 16 \\
\hline Univ Illinois & 6 & Univ Toronto & 11 & Univ Valencia & 16 \\
\hline $\begin{array}{l}\text { Hebrew } \quad \text { Univ } \\
\text { Jerusalem }\end{array}$ & 6 & Penn State Univ & 11 & Univ Minnesota & 14 \\
\hline Columbia Univ & 6 & Univ Valencia & 10 & Univ Kentucky & 14 \\
\hline $\begin{array}{l}\text { Univ Calif Los } \\
\text { Angeles }\end{array}$ & 6 & $\begin{array}{l}\text { Univ Western } \\
\text { Ontario }\end{array}$ & 10 & Univ Alicante & 14 \\
\hline Univ Washington & 6 & Univ Michigan & 9 & Boston Univ & 14 \\
\hline Boston Univ & 6 & $\begin{array}{l}\text { Hebrew Univ } \\
\text { Jerusalem }\end{array}$ & 9 & Univ Calif San Francisco & 14 \\
\hline MRC & 6 & Univ Texas & 9 & Yale Univ & 14 \\
\hline Georgia State Univ & 6 & Uppsala Univ & 9 & Karolinska Inst & 13 \\
\hline Yale Univ & 5 & Univ Manitoba & 9 & Columbia Univ & 13 \\
\hline Univ Manchester & 5 & Univ Penn & 9 & Uppsala Univ & 13 \\
\hline $\begin{array}{ll}\text { Chinese } & \text { Univ } \\
\text { Hong Kong } & \\
\end{array}$ & 5 & $\begin{array}{l}\text { Univ British } \\
\text { Columbia }\end{array}$ & 8 & NYU & 12 \\
\hline $\begin{array}{l}\text { Johns Hopkins } \\
\text { Univ }\end{array}$ & 5 & Univ Haifa & 8 & $\begin{array}{l}\text { Johns Hopkins Bloomberg Sch } \\
\text { Publ Hlth }\end{array}$ & 12 \\
\hline Wellesley Coll & 5 & Univ Hong Kong & 8 & Makerere Univ & 12 \\
\hline Penn State Univ & 5 & MRC & 8 & Univ N Carolina & 12 \\
\hline Univ Arizona & 5 & McMaster Univ & 8 & Univ Michigan & 11 \\
\hline $\begin{array}{l}\text { Michigan State } \\
\text { Univ }\end{array}$ & 5 & Yale Univ & 7 & Rutgers State Univ & 11 \\
\hline
\end{tabular}


The cooperational network on the subject of VAW among the universities will be evaluated separately.

\section{Network Structure Among The Keywords Given In Articles On VAW}

The network structure among the keywords given in the articles on VAW was evaluated with the Social Network Analysis for the period of 2000-2014. The obtained network structure drawings for three different periods are presented in Figures 9.1-9.3.

Figure 3: Articles on VAW According to The Keywords (2000-2004)

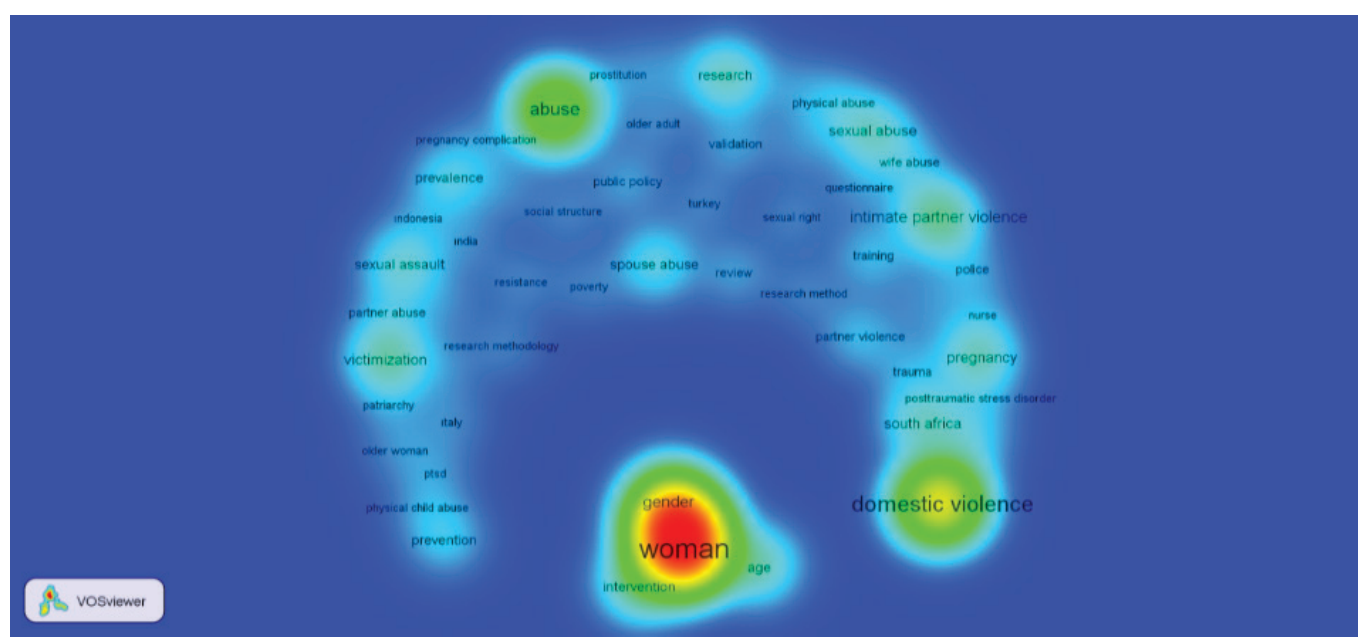

Figure 4: Articles on VAW According to The Keywords (2005-2009)

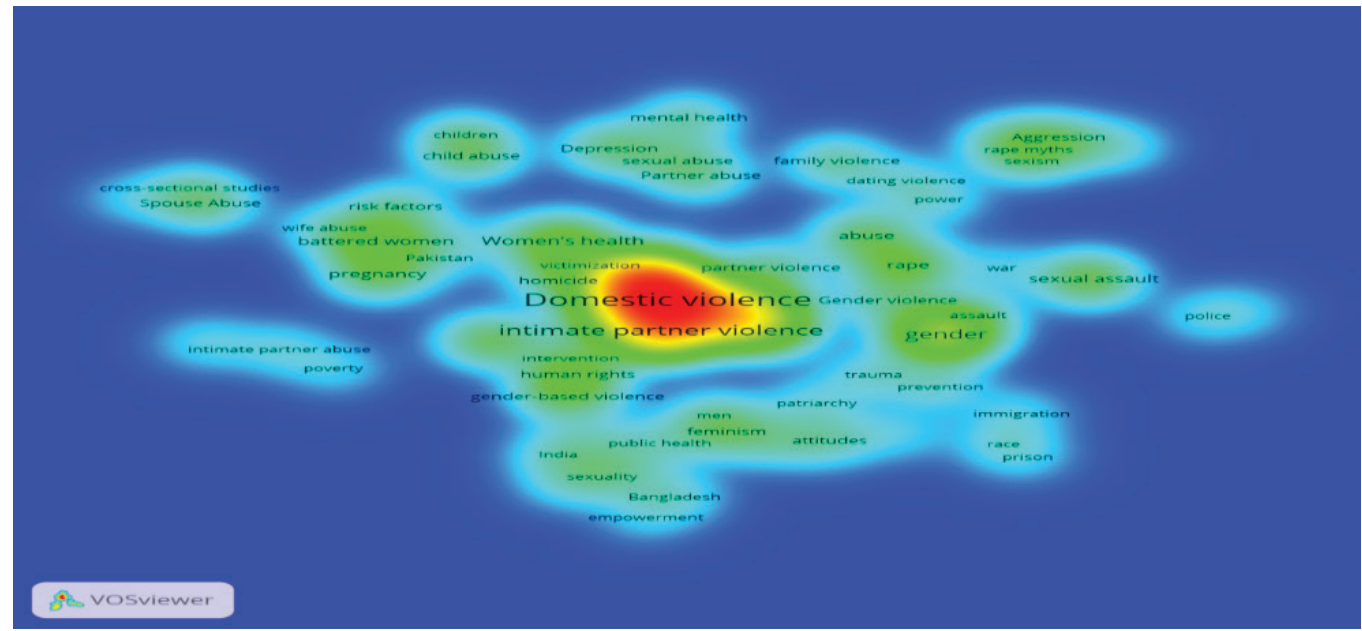


Figure 5: Articles on VAW According to The Keywords (2010-20I4)

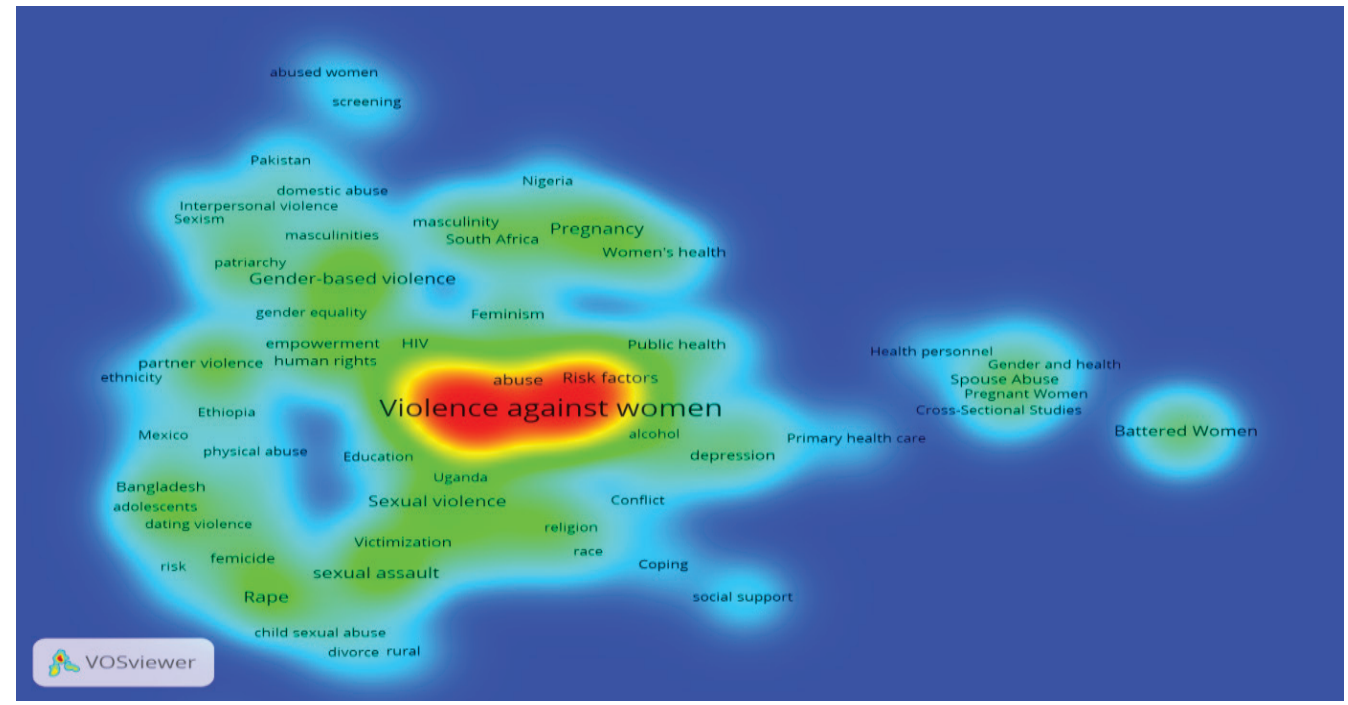

While VAW was categorized as in "women studies" in researches conducted between 2000 and 2004, it was included in the studies of "domestic violence" and "intimate partner violence" between 2005 and 2009. For the last five years period, "VAW" emerged as an individual research area. This startling result shows that studies on VAW has gained a unique place in scientific literature since 2010 .

\section{I0. Network Structure Among Countries That Publish Articles On VAW}

One of the parameters investigated within the scope of this study is the network structure among the countries which publish articles on VAW. The results of the network structure is presented in Figures 10.1-10.3.

The results shows that there was a significant increase in the network density in each five year period.

In each three period, the USA was the country having the highest co-operation with other countries while having the highest publication, as well. Between 2005 and 2009, the USA was followed by Canada, Switzerland and England as the other leading cooperative countries. It is observed that Brazil, Spain and Australia had joined them in the period from 2010 to 2014. 
i. Essen YILDIRIM • Özlem ERGÜT

Figure 6: Network Structure Among Countries Which Publish Articles on VAW (2000-2004)

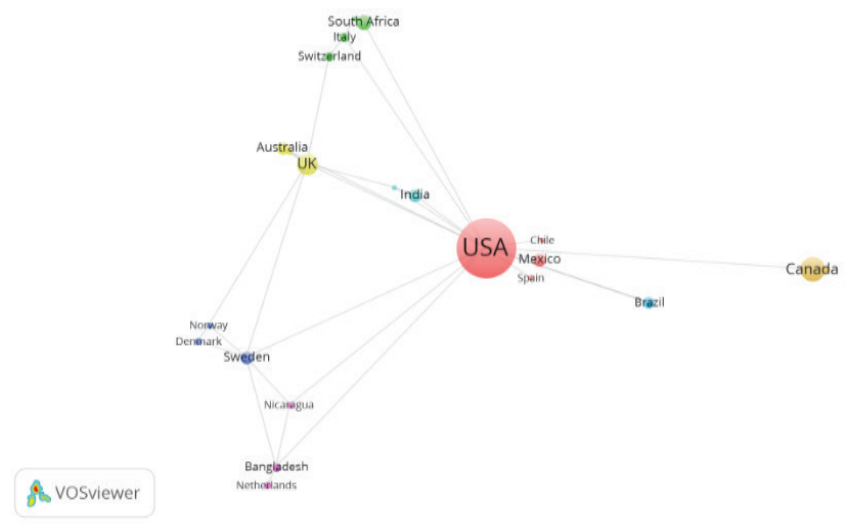

Figure 7: Network Structure Among Countries Which Publish Articles on VAW (2005-2009)

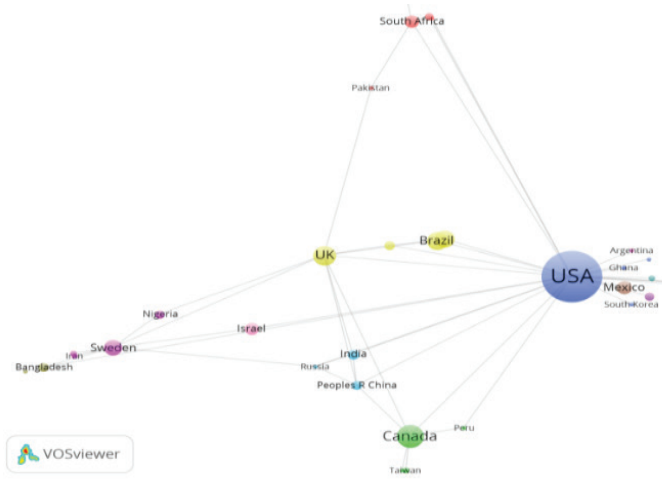

Figure 8: Network Structure Among Countries Which Publish Articles on VAW (2010-2014)

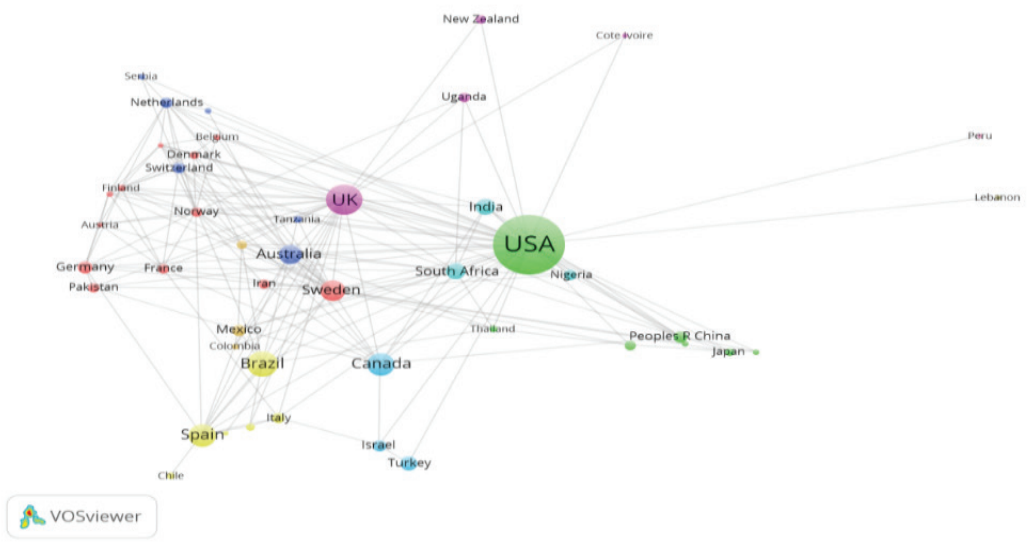

326 
The densest network structure (centralization) on VAW, with a value around 0.60 , is observed among "countries" in comparison with the "universities" and "authors" networks. Related measures are shown in Table 10.1

Table 7: Centralization, Betweennes and Clustering Measures for Countries Network

\begin{tabular}{|c|c|c|c|}
\hline & Centralization & Betweenness & Watts-Strogatz Clustering \\
\hline $\mathbf{2 0 0 0 - 2 0 0 4}$ & 0.59523810 & 0.74340155 & 0.51190476 \\
\hline $\mathbf{2 0 0 5 - 2 0 0 9}$ & 0.61428571 & 0.76855747 & 0.49798137 \\
\hline $\mathbf{2 0 1 0 - 2 0 1 4}$ & 0.61475410 & 0.41254916 & 0.69274944 \\
\hline
\end{tabular}

The "betweenness" measure is found to be quite high for the countries network when compared with the universities and authors networks since the USA is the main actor (Figures 10.1-10.3). Along with a considerable increase in the number of countries joined to the network in the last five years clustering increased while the "betweenness" measure decreased. The increase in clustering shows the densifying of communications in small groups among the countries.

\section{I. Network Structure Among Universities Which Publish Articles On VAW}

The network structure among universities which publish articles on VAW is shown in Figures 11.1-11.3. The obtained structure in the five year periods revealed that the number of actors who joined the scientific communication network increased considerably. The universities in the USA are the most observable ones on the network as a reflection of the fact that the USA is the main actor in VAW studies.

Figure 9: Network Structure Among The Universities Which Publish Articles on VAW (2000-2004)

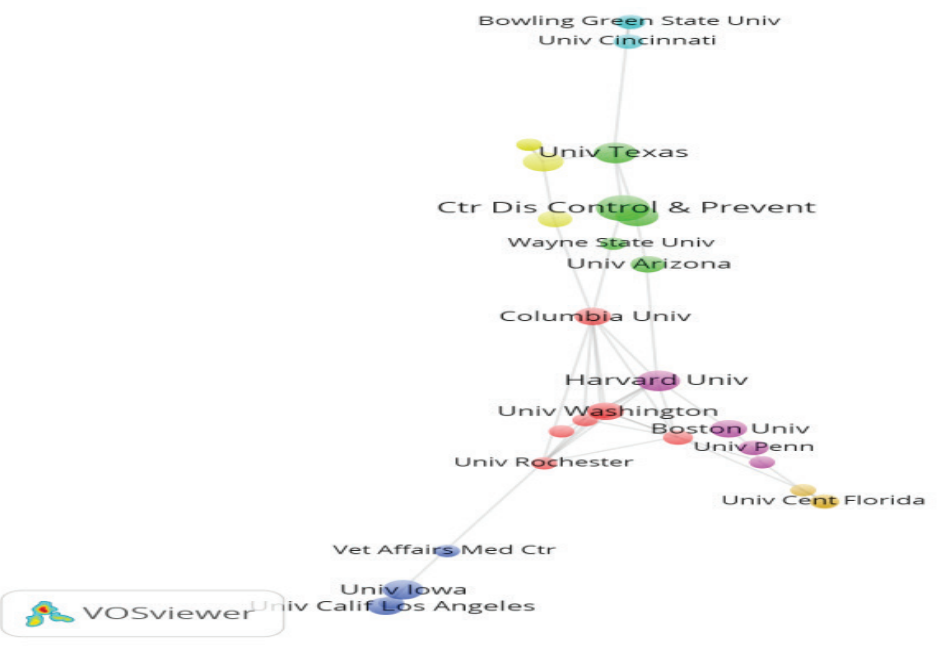


Figure I0: Network Structure Among The Universities Which Publish Articles on VAW (2005-2009)

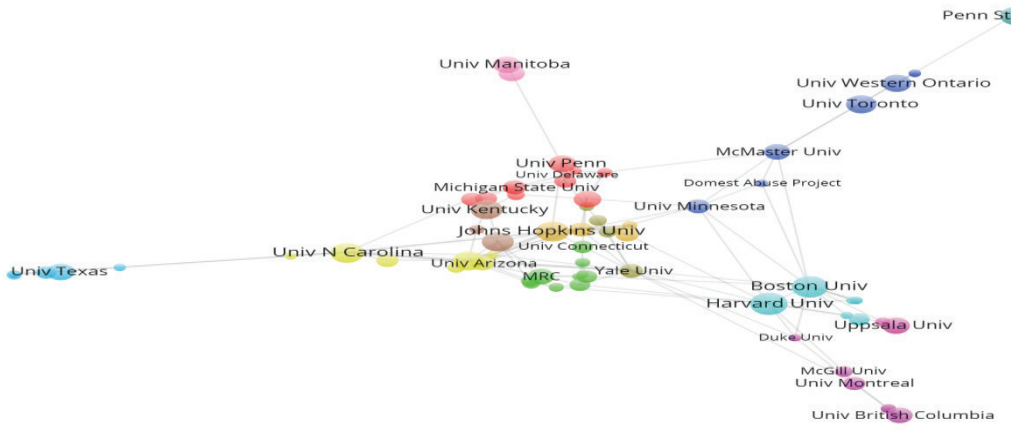

sosviewer

Figure I I: Network Structure Among The Universities Which Publish Articles on VAW (20I0-20I4)

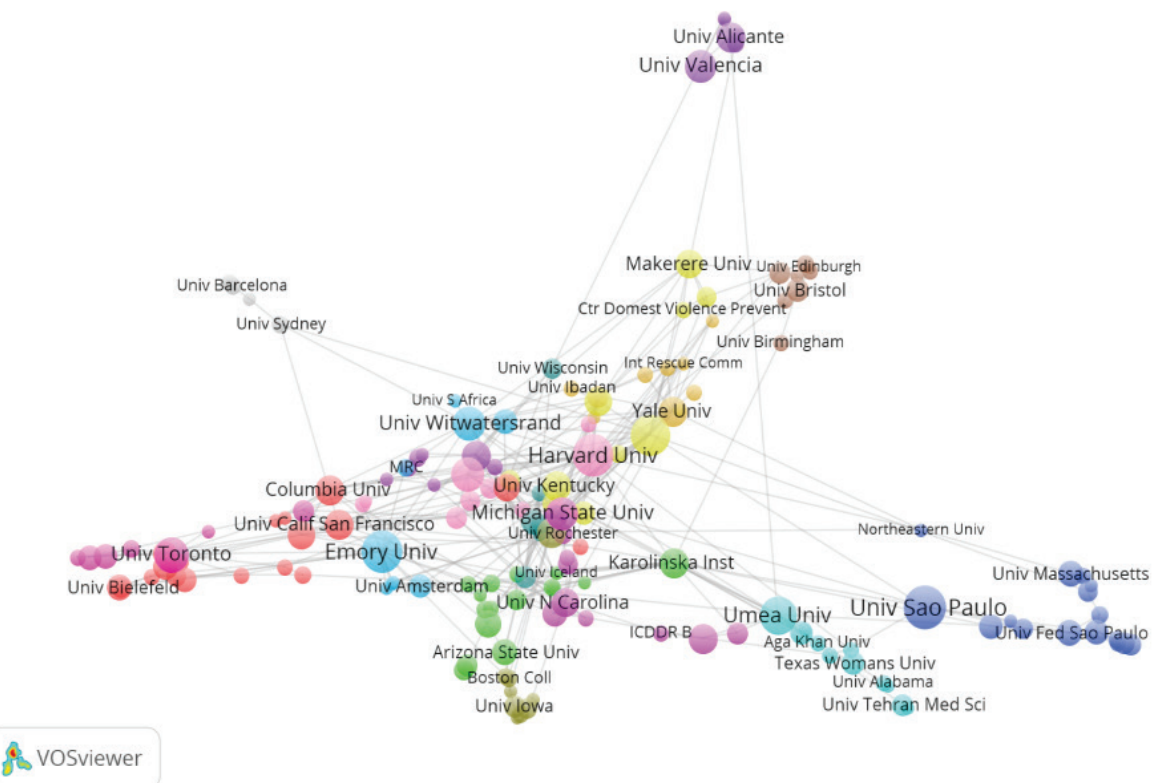

The centralization, betweenness and clustering measures for universities network is presented in Table 11. When the Table 11 is evaluated it is seen that the centralization of the "universities" network is low in comparison with the "countries" network. 
Table 8: Centralization, Betweenness and Clustering Measures for Universities Network

\begin{tabular}{|c|c|c|c|}
\hline & Centralization & Betweenness & Watts-Strogatz Clustering \\
\hline 2000-2004 & 0.14924506 & 0.22464189 & 0.53844538 \\
\hline $\mathbf{2 0 0 5 - 2 0 0 9}$ & 0.08988764 & 0.17541114 & 0.35949174 \\
\hline $\mathbf{2 0 1 0 - 2 0 1 4}$ & 0.13066758 & 0.14159261 & 0.34698192 \\
\hline
\end{tabular}

In the evaluation of Table 11, a low "betweenness" value for the "university" network indicates that there is no particular university that acts as a bridge in the network. It is also remarkable that clustering in the "university" network follows a decreasing trend by time. Here, it should be stated that, in the following section, the cooperation on the VAW studies (Clustering) was detected among the "authors", not the "universities".

\section{Network Structure Among Authors Who Publish Articles On VAW}

The results of social network analyses for the authors with publication on VAW are presented at Figure 12.1. Parallel to the increase in the number of authors and the publication per author, it was also found that the network density after 2010 also increased.

Figure 12: Network structure among authors who publish articles on VAW

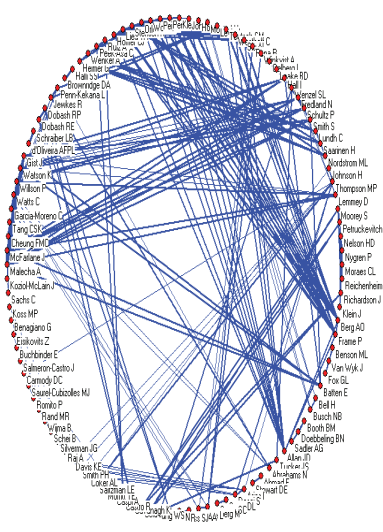

2000-2004

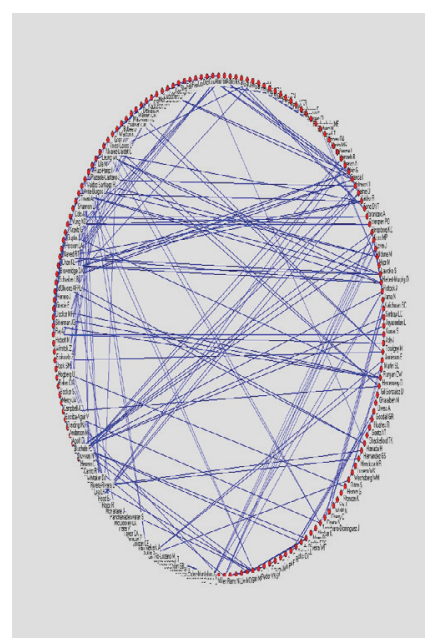

2005-2009

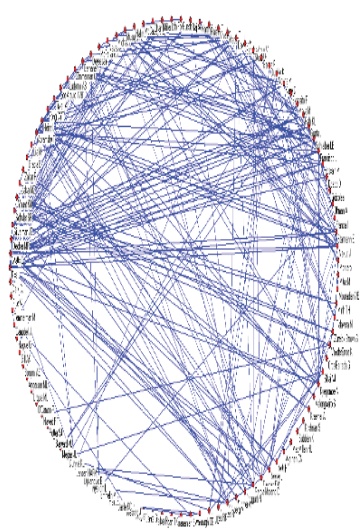

2010-2014

The centralization, betweenness and clustering measures for the "authors" network are given at Table 12.1. It is seen that the "betweenness" centrality for the "authors" network is low; which indicates that there is no leading author that acts as a bridge between other authors. However, it is observed that there is an increase in the centralization coefficients for the period of 2010-2014. This demonstrates the increased cooperation among the authors. 
Table 9: Centralization, Betweenness and Clustering Measures for Authors Network

\begin{tabular}{|c|c|c|c|}
\hline & Centralization & Betweenness & Watts-Strogatz Clustering \\
\hline $\mathbf{2 0 0 0 - 2 0 0 4}$ & 0.07509881 & 0.01443547 & 0.86666667 \\
\hline $\mathbf{2 0 0 5 - 2 0 0 9}$ & 0.07142857 & 0.00514842 & 0.90588235 \\
\hline $\mathbf{2 0 1 0 - 2 0 1 4}$ & 0.18068536 & 0.08131667 & 0.81180528 \\
\hline
\end{tabular}

At the same time, the clustering measure for the "authors" network is comparatively higher than that of the "countries" and the "universities". This result points out that there are a lot of groups studying on VAW. The prominent groups of the clusters are given in Figures 12.2-12.4.

Figure 13: Clustering Among The Authors (2000-2004)

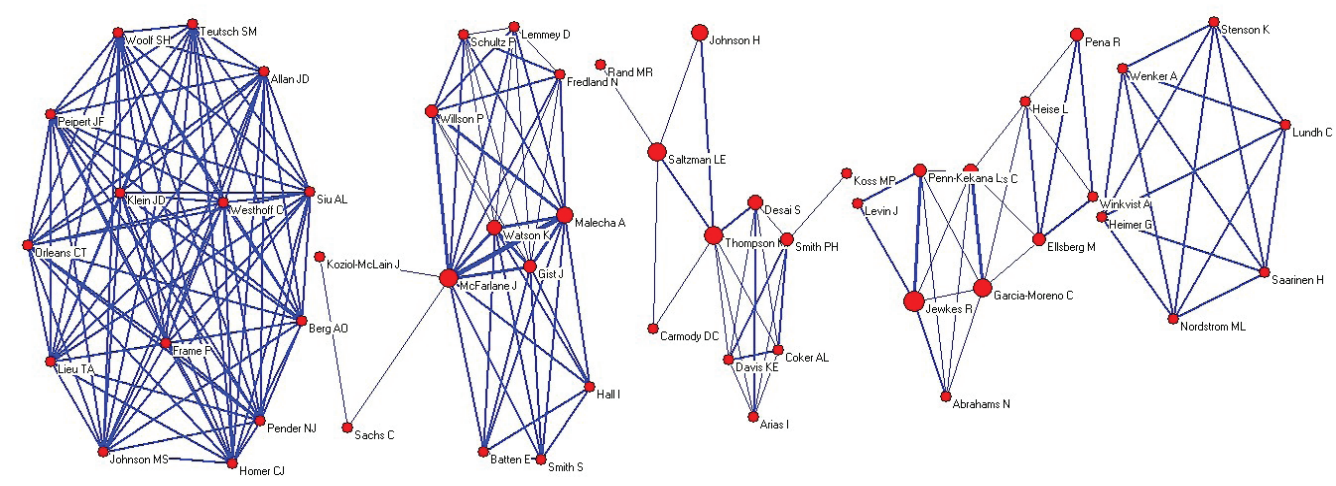

Figure 14: Clustering Among The Authors (2005-2009)

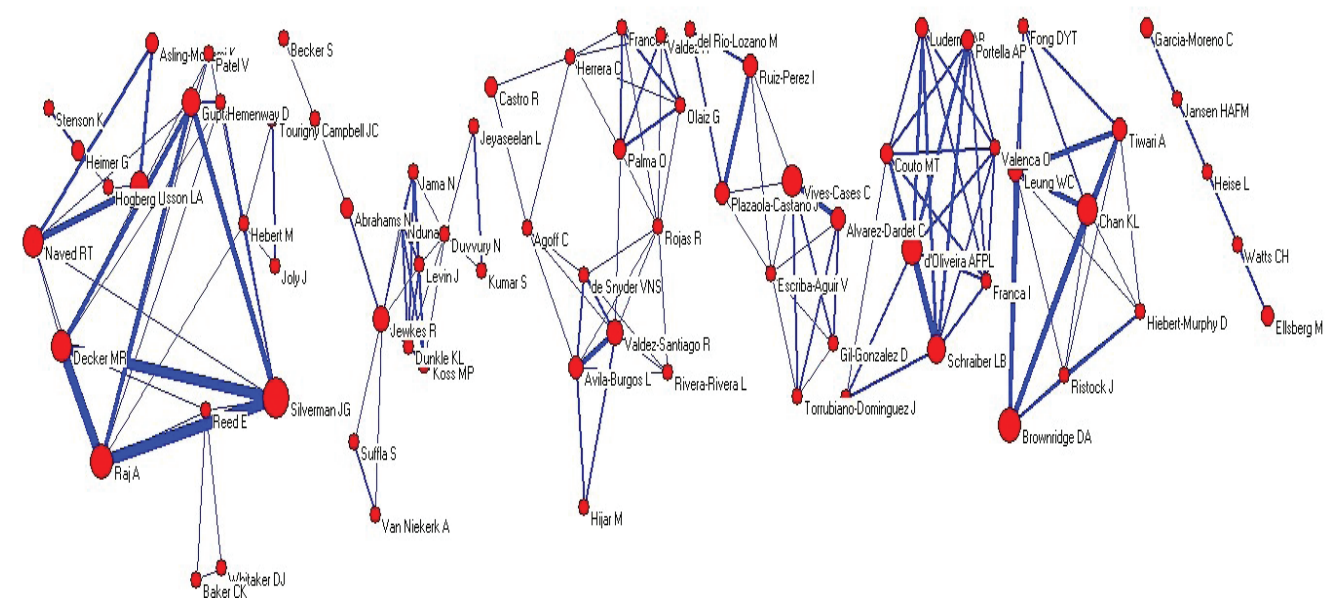


Figure 15: Clustering Among The Authors (2010-2014)

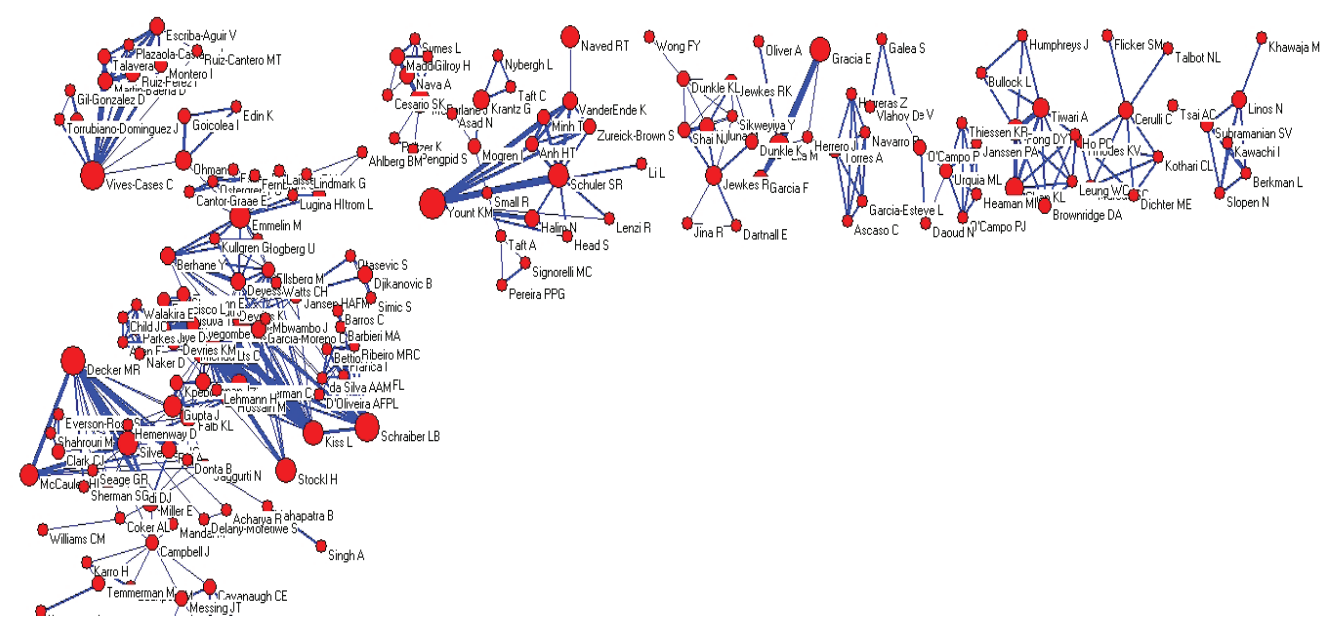

In the Figure 12.2-12.4, the nodes (authors) are shown with red circles while the connections (the cooperation among authors) are represented with blue lines. The circle representing an author grows with the increase in the number of publication of that author. From this fact, the authors making the highest contribution to the literature on VAW can be easily detected from the figures. Similarly, the blue lines demonstrating the cooperation among authors thickens with the increase in the number of joint publication of authors. This enables the easy detection of researchers having the highest cooperative study.

The detailed evaluation of the Figures 12.2 and 12.3 presents important signs for the research groups studying on VAW. For example; the first cluster in Figure 12.2 demonstrates the coauthorship among 12.3 authors. Similarly, the thickened blue lines between the authors in Figure 12.3 point out the increased collaborative works among these authors. As can be seen from Figure 12.4, both the number of groups and the involving authors in groups are increased after 2010.

\section{Conclusion}

This study investigated the bibliometric analyses of VAW literature since 2000. The bibliometric studies use keywords for the evolution of publications on the particular subject. The publications that were studied within the scope of this research were, therefore, filtered through the "Web of Science" database with the keyword of "violence against women" since 2000.

It is observed that there is no unique keyword on the selected subject; different researchers have preferred to use many similar but also different keywords such as "Violence against Women", "Violence against Woman", "VAW", "Violence (Against Women)", "Violence against Women and Girls" in VAW literature. This lack of unity of terminology in keywords used in the publications 
on VAW cause significant difficulties in compiling the data set. For that reason; the appropriate selection of keywords and agreement on indexing terms by the authors are two very important issues in supporting the proper conditions required for the bibliometric studies.

Recent studies revealed that the interest of scientists on the subject of VAW has followed an increasing trend especially starting from the year 2000, which made the subject of VAW become a unique field in the literature. It is clear that the urgent development of bibliometric database for the literature on VAW and continuous implementations of bibliometric analyses has become a necessity. Collaborations with biostatisticians may open new avenues for statistical analyses and sophisticated methodologies. In this way, the forthcoming studies that will be conducted on previously obtained scientific data through the researches on VAW will help to find out the most needed topics.

The most commonly studied fields on the subject of VAW are known to be women studies, public environmental occupational health, family studies, criminology, psychology, medicine internal and social sciences, psychiatry, sociology and law. This large scope of VAW has brought many difficulties especially for the communications among the researchers. Therefore, the development of an electronic database for VAW researchers is inevitable. The coordination of more interdisciplinary scientific meetings, where researchers who operate with different theoretical models and constructs come together around a common problem or task, would also be of benefit.

Major gaps in these type of researches is the lack of study on the causes and general means of controlling violence. There is a necessity to develop continuous surveys to analyze the prevalence and incidence of violence against women including criminal justice impacts at both the national and regional levels to protect the women against the violence.

The USA has been found to be the country making the highest contribution to the VAW literature. The highest funds provided in the USA for the research on VAW is believed to be the natural cause for this position. It should be emphasized that the allocated funds for the subject of VAW is therefore crucially important especially in the countries which the occurrance of VAW incidents are high.

There have also not been readily accessible opportunities to network with other VAW researchers through scientific meetings or associations as those are generally organized around this discipline. In this regard, the obtained data in this study and presented social network structures among countries, universities and authors can be used with this purpose. By identifying the leading institutions and authors, the formation of many useful international organizations for the development of solution suggestion and the improvement of VAW statistics can be possible. Similarly, research centers can be founded for the improvement of international cooperative works among the leading universities and researchers on VAW. Without significant change in the structure of research through the suggested international collaborative researches, the existing evaluation of data will not be enough for a proper assessment to make significant contribution to the development of policies for legal interventions to protect women. 


\section{References}

CLARK, C. William ve Dickson, M. Nancy, "Sustainability science: The emerging research program", Proceedings of the National Academy of Sciences of the United States of America, Vol.100, No.14, 2003, s.8059-8061.

CROWELL, Nancy ve Burgess, Ann, Understanding Violence Against Women, Washington, DC: National Academy Press, 1996.

European Union Agency for Fundamental Rights, Violence Against Women: An EU-Wide Survey, 2014.

FOLLINGSTAD, R. Diane, "Rethinking current approaches to psychological abuse: Conceptual and methodological issues", Aggression and Violent Behavior, Vol.12, Issue 4, 2007, s.439-458.

FORD, A. David, Bachman R., Friend M., Meloy M., Controlling Violence Against Women: A Research Perspective On The 1994 VAWA's Criminal Justice Impacts. Washington, DC: U.S. Department of Justice, NIJ, 2002.

GARFIELD, E., “The Mystery of The Transposed Journal Lists: Wherein Bradford’s Law of Scattering Is Generalized to Garfield's Law of Concentration”, Essays of an Information Scientist, Vol.1, 1977, s.222-223.

JORDAN, E. Carol, "Advancing the Study of Violence Against Women: Evolving Research Agendas Into Science", Violence Against Women, 15, 2009, s. 393-419.

KRUTTSCHNITT, Candace, McLaughlin, B., Petrie, C.., Advancing the Federal Research Agenda on Violence Against Women, Washington, DC: National Academy Press, 2002.

OTTE, Evelien ve Rousseau, Ronald, "Social Network Analysis: A Powerful Strategy, Also For The Information Sciences", Journal of Information Science, 28(6), 2002, s.441-453.

RICHIE, E. Beth, "Research on Violence Against Women and Family Violence: The Challenges and The Promise", Violence Against Women and Family Violence: Developments in Research, Practice and Policy, Ed: B. S. Fisher Rockville, MD: National Criminal Justice Reference Service, 2004, s. IV1-3-IV-1-8.

SENGUPTA, I.N., "Bibliometrics, informetrics, scientometrics, and librametrics: An overview", Libri, 42(2), 1992, s.75-98.

United Nations, The World's Women 2015, Trends and Statistics, 2015.

UNICEF, Ending Child Marriage Progress and Prospects, 2014.

World Health Organization, Violence Against Women, İntimate Partner and Sexual Violence Against Women, 2013.

http://homepage.univie.ac.at/juan.gorraiz/bibexcel/

http://www.vosviewer.com/

http://vlado.fmf.uni-lj.si/pub/networks/pajek/ 
